\title{
Mixed Methods Development of a Leadership Framework for Generation Y Bedside Nurses
}

\author{
Theresa Anne Manson ${ }^{1}$, Maureen Nokuthula Sibiya ${ }^{2}$ \& Zerish Zethu Nkosi ${ }^{3}$ \\ ${ }^{1} \mathrm{PhD}$ Graduate, Faculty of Health Sciences, Durban University of Technology, Durban, South Africa \\ ${ }^{2}$ Faculty of Health Sciences, Durban University of Technology, Durban, South Africa \\ ${ }^{3}$ College of Human Science, University of South Africa, Pretoria, South Africa \\ Correspondence: Theresa Manson, PhD Graduate, Faculty of Health Sciences, Durban University of Technology, \\ P.O. Box 1334, Durban, 4000, South Africa. Tel: 27-82-505-2514. E-mail: terry.manson6@gmail.com
}

Received: November 10, 2019 Accepted: December 19, 2019 Online Published: December 29, 2019

doi:10.5539/gjhs.v12n1p124 URL: https://doi.org/10.5539/gjhs.v12n1p124

\begin{abstract}
This study addresses the global leadership crisis in healthcare, which leaves an unprepared nursing workforce who are unable to achieve acceptable patient outcomes. Generation Y nurses will soon form the majority cohort of nurses; they therefore represent the future of the nursing profession worldwide. Their leadership ability will no doubt impact on healthcare globally. There has been a lack of academic research focusing on the leadership needs of Generation Y nurses, specifically bedside nurses who are closest to the point of care. There is also a lack of mixed methods research in this field. This research answers the question: How can the nursing profession prepare Generation Y nurses to become effective leaders? A multistage mixed methods advanced framework design was used, with data integration occurring at multiple levels. Data was collected on Generation Y nurses working at a hospital in Saudi Arabia, through the Values in action (VIA)-24 strengths survey, the American Organization of Nurse Executives (AONE) leadership survey on 'The leader within', and semi-structured face-to-face interviews. Data analysis included statistical measures and thematic analysis using Tesch's coding. The aim of the study was to develop a sustainable leadership framework for generation Y bedside nurses, through data collected from them and for them. This study shows that Generation Y nurses have a clear leadership vision, and strongly desire leadership education that is creative, innovative, technology-driven and fun. It is vital that bedside nurses are given the opportunity to meet their full leadership potential, which will contribute towards the much needed transformation of healthcare globally.
\end{abstract}

Keywords: Bedside nurse, Generation Y, leadership, nursing leadership

\section{Introduction and Background}

There is a lack of effective leadership in healthcare, which, according to the World Health Organization (WHO) constitutes a global crisis (WHO, 2015). The healthcare workforce is said to be currently unprepared for the ever-increasing healthcare needs (Sherman, Dyess, \& Prestia, 2013). Because healthcare delivery relies on good leadership, a lack thereof can have an enormous impact on patient outcomes (West et al., 2014). Nurses form the backbone of any healthcare organisation; they make up 40-50\% of any healthcare workforce (Stanley, 2010). They therefore have a key role to play in the provision of universal health coverage (Mitchell, 2015; WHO, 2013), especially at the point of care (Sherman \& Pross, 2010). It is predicted that by the end of this decade, there will be a worldwide shortage of nurse leaders, which will be a key challenge to rectify (Dyess et al., 2016; Holland, 2015; Sherman, Dyess, \& Prestia, 2013).

In response to the need to revitalise healthcare, the United Nations (UN) has identified sustainable development goals (SDG) to be achieved over the next 15 years by the target date of 2030 (WHO, 2015). These unique goals call for global action by all WHO member states (rich, poor and middle-income) to promote prosperity through building economic growth and by addressing a range of social needs including health. One of the goals is to strengthen health systems through effective healthcare leadership development (WHO, 2015). Pierre Théraulaz said in the International Council of Nurses (ICN) Global Leadership Institute report that if the nursing profession want their voices heard, they must strengthen nursing leadership (ICN, 2016).

Leaders create the future and are responsible for the essential role of providing good leadership. Leadership is a 
multifaceted phenomenon for which no universal definition exists, yet many theories have been proposed. Although leaders and managers are crucial to organisations, the terms 'leadership' and 'management' are often confused and erroneously interchanged (Kotter, 2013). Although there are similarities between the two, there are also distinct differences: managers deal with the operational activities at work, whereas leaders influence people. A suggested definition of leadership is that it is a relationship between a leader and members of a team, all of whom focus on a common goal. The leader is accountable and should behave with integrity when influencing the team. This definition could not be more appropriate for leaders in healthcare, where good leadership skills are needed to make safe and effective decisions for patients and co-workers.

Nurses are knowledge experts, and according to Grossman and Valiga (2017) they lead at all levels, not only from formal leadership positions. Supporting the notion that everyone is a potential leader, Benne (1948) believes that anyone can lead, given the opportunity and adequate support. It is thus crucial to promote appropriate leadership development at all levels of nursing (IOM, 2011; Medyanik, 2016; Mitchell, 2015), including bedside nurses (Byers, 2017), because bedside nurses make decisions requiring good leadership on a day-to-day basis (Manson, 2019). According to the National Health Service (NHS, 2011) it is during times of change that the healthcare industry needs to develop robust internal capacity, to optimise leadership potential across all levels of the healthcare profession. In fact leadership is a professional responsibility of every single nurse.

The American Hospital Association (AHA) estimates that by 2020, fifty percent of the global workforce will comprise the younger generation known as Generation Y (AHA, 2014). Generation Y individuals are those born between 1980 and 2000 (Chung \& Fitzsimons, 2013; Manson, 2019). It is therefore imperative that strategies to meet their expectations are put in place to prepare them to lead the future of nursing. There is a lack of literature on nursing leadership relating to generational needs. According to Tulgan (2009) the younger generations need strong leadership and Woodward, Vongswasdi and More (2015) found them to have unique leadership needs. The literature tells us that Generation Y are more complex to lead (Hewitt \& Upkere, 2012; Nelsey \& Brownie, 2012); in fact they prefer to be 'led' rather than 'managed' (Holt, Marques, \& Way, 2012; Tulgan, 2009), thus leadership development should be appropriately adapted for them. This means that in order to ensure a successful future for healthcare, hospitals need to focus on better developing effective leaders within the Generation Y cohort (Dyess et al., 2016; Holt, Marques, \& Way, 2012; Manson, 2019; Nelsey \& Brownie, 2012). There are currently four generation working together, resulting in changes to the nursing hierarchy from a traditionally tiered structure, to one that is less hierarchical. This means that younger, inexperienced nurses have become more assertive and less dependent on the older nurses with years of experience (Hendricks \& Cope, 2012).

With appropriate leadership, great effectiveness can be achieved in a healthcare environment that is experiencing continual change. Rapid changes in healthcare have led to the need to revisit the way leaders are developed. When healthcare leaders look to the research to find ways to meet these healthcare challenges, they will find gaps. New and creative leadership approaches are needed. Most previous research on leadership is quantitative in nature which is limiting, because simply put, statistical analysis does not do justice to understanding the complexity of leadership.

Saudi Arabia is a middle-income Islamic country that relies heavily on expatriate nurses. While hospitals in Saudi Arabia are generally well-equipped with state-of-the-art consumables and equipment using the latest technology, their healthcare is not supported by a local and experienced nursing workforce (Manson, 2019). There are many challenges when it comes to nursing in Saudi Arabia, including that female Saudi nurses prefer not to work weekends, long hours, late shifts or night duty (Manson, 2019). This leads to the need to hire expatriates to staff their hospitals. As a result the average Saudi Arabian nursing workforce is made up of only $34 \%$ Saudi nurses (AlYami \& Watson, 2014). Due to the economic situation and unemployment of qualified nurses in the Philippines, 'Filipino' nurses, as they are referred to, are now working in most countries around the world, including large numbers who nurse in Saudi Arabia. The leadership ability of Filipino nurses will no doubt impact on healthcare worldwide (Manson, 2019).

The Relationship-Based Care (RBC) model serves as the theoretical framework for the study (Koloroutis, 2004). This study addresses the global leadership crisis in healthcare, and answers the question: How can the nursing profession prepare Generation Y nurses to become effective leaders? The aim of the study was to understand generation Y nurses with regard to their character strengths, their current leadership skills, and their unique leadership development needs. From the data, the study aimed to develop a leadership framework to address the leadership crisis and prepare the younger generation to take the lead from the bedside and beyond.

\section{Methods}

Because care is provided through relationships, the individual nurse, as a care provider, has a pivotal impact on 
patient satisfaction and outcomes (Manson, 2019). The RBC model formed the foundation for the study and guided multiple stages, namely the research design, problem, questions, aim, significance, literature review, results, and ultimately the development of the leadership framework. This model is based on six dimensions, namely: a) teamwork, b) leadership, c) professional practice, d) resource driven practice, e) patient care delivery, and f) outcomes measurement. To fulfil the aim of this study, only four of the dimensions mentioned above were used, namely: teamwork, leadership, professional nursing practice and resources. The RBC centres on the needs of the patient and family and it lends itself to the leadership development of bedside nurses. The nurse as a professional is portrayed as an important component of the resource dimension. In this model professional growth and personal development are seen to be an integrated whole, with a focus on self-awareness, nurturing healthy relationships and developing leadership ability (Koloroutis, 2004). The leadership and teamwork dimensions, in a relationship-based context, were well integrated in the study to contextualise the findings and discussion.

\subsection{Study Design}

Leadership is both complex and multifaceted, which poses challenges for the researcher to record and examine it. The researcher's pragmatic philosophy is that people are viewed within their surroundings through a lens of interconnectedness. The creative mixed methods study design that was utilised, falls within the category 'advanced frameworks', identified by Fetters, Curry and Creswell (2013). Data integration occurs at multiple levels. Figure 1 illustrates the research design, showing the quantitative and qualitative components of the study phases.
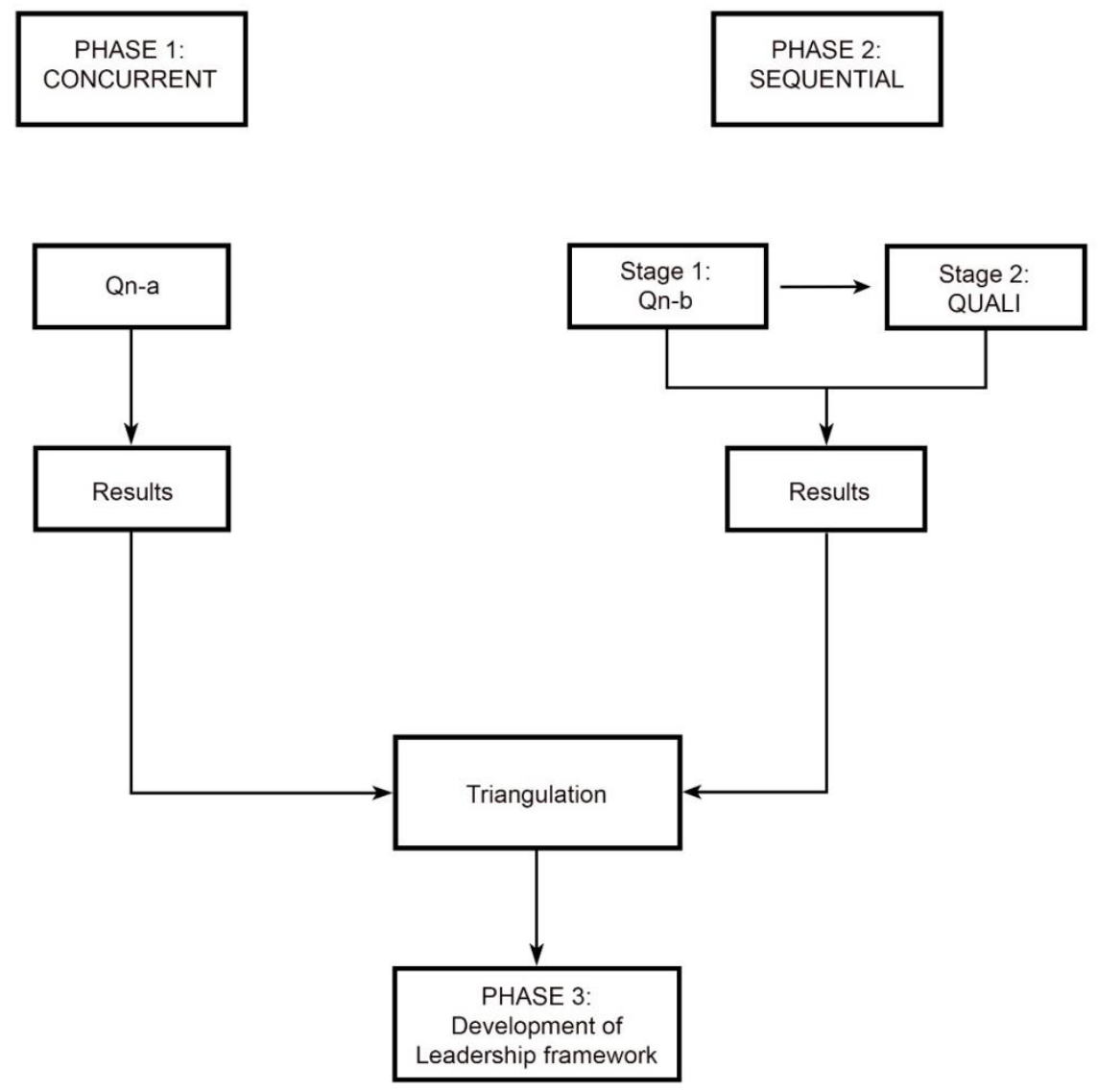

Figure 1. Research design

\subsection{Study Setting}

This urban study took place in the capital city of Saudi Arabia, at a general hospital which provides 24 hour care to patients. The majority of nurses working at this hospital are nationals of the Philippines, known as 'Filipino'. The sample was bedside nurses assigned to 16 clinical areas, with most working 12-hour rotational day and night shifts.

\subsection{Population and Sampling}

The researcher used a combination of purposive sampling methods, so as to enhance the study (Polit \& Beck, 
2012). There were two phases of data collection, each with a different sampling method. The first phase (concurrent) applied a quota sampling method for collecting data from an online strengths survey. The study sample was calculated assuming an alpha level of .05 and a margin of error of .05 . While the population of nurses at the study site was 269 , only 218 satisfied the inclusion criteria for the study and became the study population. Using an alpha value of .05 and a margin of error of .053, the adjusted sample size calculated is 342 , according to Cochran's formula (Bartlett, Kotrlik, \& Higgins, 2001). However, since this sample size exceeds 5\% of the population, Cochran's correction formula is applied as follows:

$\mathrm{n}=342 /(1+342 / 218)=134$ (where 218 is the study population)

The second phase (sequential) applied a random sampling approach (fishbowl method), for collecting mixed data, firstly from a survey (quantitative) followed by an interview (qualitative). Selection criteria for this study was that participants had to be over the age of 18 years, nationals of the Philippines, and from the Generation Y cohort. The sample comprised both male and female professional nurses, referred to as 'staff nurses' in Saudi Arabia. The qualitative sample size was determined by the principle of data saturation described by Polit and Beck (2012) which occurs when no new themes arise during analysis and when data becomes repetitive and redundant in subsequent interviews. Data saturation was reached after 12 participants were interviewed, $76 \%$ females and $24 \%$ males.

\subsection{Data Collection}

There were two data collection phases to the study, as shown in Figure 1, using three research instruments. The first phase (concurrent) collected data from the VIA-120 survey (QN-a). The second phase (sequential) comprised the collection of data in two sequenced stages: Stage one (quantitative) made use of the AONE leadership survey (Qn-b), followed by phase two (qualitative) which used a semi-structured face-to-face interview with open-ended questions. Relative priority was given to the qualitative data (QUALI), because it was the personal views and experiences of the target population that the researcher was particularly interested in gaining knowledge about. The research instruments are described below:

- $\quad$ VIA-120 online strength survey (Qn-a): The first phase (concurrent) comprised the collection of quantitative data using the VIA-120 survey (Qn-a), which ranks 24 personal character strengths (VIA, 2017). The VIA-120 strengths survey was found to have internal consistencies for the 24 scales, with Cronbach's $\alpha$-coefficients of 0.70 to 0.88 , evidencing the reliability of the tool for use in the study (Littman-Ovadia, Lavy, \& Boiman-Meshita, 2016).

- $\quad$ AONE leadership survey (Qn-b): This survey can be found online, and according to Neu (2017) the tool was developed through the combined effort of the AONE, The American Association of Critical-Care Nurses (AACN), and The Association of periOperative Registered Nurses (AORN). The AONE is a globally acclaimed organisation of nursing leaders, and a subsidiary of the AHA. The AONE claims to be the only organisation dedicated to the specialised field of nursing leadership. The tool was developed in 2004 and job analysis and role delineation studies are periodically conducted to ensure the results are consistent when used repeatedly (Fabrey \& Traynor, 2014). For the purpose of this study, permission was granted by the AONE to utilise only the section: 'The leader within'. This tool is a self-administered survey where participants rate each leadership skill according to a five-point rating scale (AONE, 2015).

- Interview questions (QUALI): The nine interview questions were developed by the researcher, using a number of sources, namely the RBC book (Koloroutis, 2004); interview questions created by Sherman, Dyess and Prestia (2013); the knowledge of the researcher as an experienced nurse leader; other expert nursing leaders; and the study objectives. Input was also sought from Generation Y nurses who undertook a pilot study.

\subsection{Data Analysis}

The data from the two quantitative surveys were statistically analysed using the Statistical Package for Social Sciences (SPSS) version, 22.0. Inferential statistical analysis included both parametric and non-parametric tests to help draw conclusions about the population characteristics based on the study sample. Throughout the analysis, p-values of $<0.05$ were used to measure statistical significance. Qualitative data analysis began during each interview, where the researcher wrote field notes and did a preliminary analysis to identify information and themes. Each interview recording was then transcribed into text, using Microsoft Word. Thematic analysis was applied to the qualitative data, using the steps recommended by Tesch (1990). The four elements of the adapted RBC model formed the main themes, while the application of manual coding identified patterns and relationships in the data. The coding revealed eight salient sub-themes, revealed in Table 2 . 


\subsubsection{Merging Sequential Quantitative and Qualitative Data}

When and how merging took place was carefully planned and explicitly specified by the researcher, as described by Creswell et al. (2011). Data from the concurrent and sequential phases were analysed independently as described above. The sequential data was then merged to compare and substantiate the quantitative findings with the qualitative findings. This was followed by the researcher studying the findings of all three sets of data as well as the integrated findings, so as to interpret them and make inferences and meta-inferences.

\subsubsection{Integration Levels in the Study}

Integration of findings occurred at multiple levels in the study, as suggested by Creswell et al. (2003) and Fetters, Curry and Creswell (2013). Table 1 displays the four levels of integration applied to this study.

Table 1. Multi-level integration in the study

\begin{tabular}{ll}
\hline Integration level & Approach explained \\
\hline Design level & Multistage mixed methods framework: \\
& The individual nurse's experience of a complex phenomenon such as leadership is better \\
described using multiple sets of data. & Sequential phase: \\
Methods level & $\begin{array}{l}\text { One data set connects with another through the identical study sample. The two sequential sets } \\
\text { of data (Qn-a and QUALI) were integrated during data collection and were also merged after } \\
\text { analysis, to combine, compare, and substantiate results. After independent analysis of the } \\
\text { different sets of data, the quantitative data was embedded in the qualitative. }\end{array}$ \\
& $\begin{array}{l}\text { Sequential phase: } \\
\text { Presentation of results } \\
\text { level }\end{array}$ \\
Quantitative and qualitative results were presented separately using statistical and staged \\
narrative approaches respectively. Findings of both sets were then merged to compare and \\
substantiate findings. \\
Narrative weaving approach: \\
$\begin{array}{l}\text { This approach was used to link concurrent and sequential findings after analysis. Findings were } \\
\text { level }\end{array}$ \\
$\begin{array}{l}\text { triangulated and discussed together, affording relative priority to the qualitative themes and } \\
\text { sub-themes as the framework. This woven data then formed the leadership framework (phase } \\
\text { three). }\end{array}$
\end{tabular}

\subsection{Trustworthiness}

To ensure the quality of the research data, four criteria were considered: credibility, dependability, confirmability and transferability (Lincoln \& Guba, 1985). Credibility was ensured through sound sampling and data collection methods. Creating a suitable set of interview questions which were used for each participant increased credibility, as did methodological triangulation of the data collected, recording of the interviews, using the quotes in the presentation of the results, collection of multiple sources of data, and through the method of data saturation. Dependability was maintained because the key informants met the selection criteria. No other sample can answer questions about their leadership perceptions, but them. Confirmability was demonstrated by the researcher checking the interview transcripts repeatedly to ensure no relevant points were missed, and to ensure that interpretation of the results remained congruent with the findings. Rigorous triangulation during the third phase ensured that the proposed leadership framework was an accurate reflection of the findings, as did obtaining experts to review the new framework. Transferability was achieved through robust data collection and analysis, and although external validity of the leadership framework has not been proven, the results are provided should another interested party wish to project the findings onto other groups or other contexts.

\subsection{Ethical Considerations}

Permission to conduct the study was given by the accredited Institutional Research Ethics Committee (IREC), after approving the proposed research plan. Full ethical clearance was received prior to commencing the data collection. In addition, the researcher was required to undergo a Bioethics online training course prior to approval being granted by the affiliated Institutional Review Board (IRB) in Saudi Arabia. A statistician was consulted to guide the sample size and the statistical analysis of the quantitative data. The participants were informed of the 
study details and voluntarily signed informed consent to understanding the study, namely: purpose, nature of the study, data collection methods, benefits, risks, and to their right to withdraw at any time. The researcher alone had access to the data collected, and anonymity was maintained as no names were recorded on the data collection tools, but rather a code was used. Confidentiality of the interview data in the form of audio recordings, field notes and transcribed records was maintained by storage on the researcher's laptop, with a code known only to the researcher.

\section{Results}

Table 2 reveals the results of the analysis of three sets of mixed data.

Table 2. Summary of integrated findings

\begin{tabular}{|c|c|c|}
\hline Theme & Sub-theme & Findings \\
\hline \multirow[t]{2}{*}{ 1.Leadership } & $\begin{array}{l}\text { 1.1 Leaders and } \\
\text { leadership }\end{array}$ & $\begin{array}{l}\text { Define a leader as: a role model, positive, confident decision-maker and } \\
\text { influencer. Believe their ability to speak well will increase their self-confidence to } \\
\text { lead. }\end{array}$ \\
\hline & $\begin{array}{l}\text { 1.2 Bedside } \\
\text { leaders }\end{array}$ & $\begin{array}{l}\text { Have leadership vision and strongly believe anyone can lead, even at the bedside, } \\
\text { regardless of years of experience. Believe they have leadership ability. They are } \\
\text { keen to take the lead and want equal opportunity to practice leadership skills. }\end{array}$ \\
\hline \multirow[t]{2}{*}{ 2. Teamwork } & 2.1 Knowing self & $\begin{array}{l}\text { Perceive effective leaders to be self-aware. The character strength 'Fairness' was } \\
\text { rated highest out of } 24 \text { strengths. }\end{array}$ \\
\hline & $\begin{array}{l}2.2 \text { Relationship } \\
\text { with others }\end{array}$ & $\begin{array}{l}\text { Value collaborative teamwork and good communication, specifically listening } \\
\text { skills. Relationships and getting to know subordinates are important. The } \\
\text { character strength 'Teamwork' was rated in the top eight out of } 24 \text { strengths by } \\
62 \% \text { of participants. }\end{array}$ \\
\hline \multirow[t]{2}{*}{$\begin{array}{l}\text { 3.Professional } \\
\text { practice }\end{array}$} & $\begin{array}{l}\text { 3.1 Current } \\
\text { practice } \\
\text { environment }\end{array}$ & $\begin{array}{l}\text { Believe leaders influence the practice environment. A non-punitive environment } \\
\text { is desirable. They want their voices heard and to be part of decision-making. They } \\
\text { want their leader to support them. }\end{array}$ \\
\hline & $\begin{array}{l}\text { 3.2 Professional } \\
\text { growth }\end{array}$ & $\begin{array}{l}\text { Want to be challenged and do not want to be bored. Desire a clear individualized } \\
\text { career path. }\end{array}$ \\
\hline \multirow[t]{2}{*}{ 4. Resources } & $\begin{array}{l}\text { 4.1 Previous } \\
\text { experience }\end{array}$ & $\begin{array}{l}\text { Have gained leadership development through team-building games, projects, } \\
\text { evidence-based activities, precepting new staff, taking turns to be shift leader, } \\
\text { being a committee member, doing presentations in front of others, and } \\
\text { participating in policy development. }\end{array}$ \\
\hline & $\begin{array}{l}\text { 4.2 Future } \\
\text { expectations }\end{array}$ & $\begin{array}{l}\text { Strongly desire leadership education that is creative, innovative, } \\
\text { technology-driven and fun. The character strength 'Humour' was rated in the top } \\
\text { 10. Development must include leadership skills for personal and professional } \\
\text { development: to improve self-confidence, self-awareness, and management of } \\
\text { self (emotions). Need skills to manage others regarding conflict, problem-solving } \\
\text { and decision-making. Team-building activities are desired. }\end{array}$ \\
\hline
\end{tabular}

\section{Discussion of Results}

The quantitative and qualitative data were merged and integrated, and will be discussed according to the RBC themes and the sub-themes that emerged from the data.

\subsection{Theme 1: Leadership}

\subsubsection{Leaders and Leadership}

Participants used a wide variety of positive words to describe a leader, which aligns with both authors Klann (2007) and Medyanick (2016) who refer to the positive influence exerted by a leader, and how a leader sets an example in attitude as well as behaviour, which leads to followers mimicking their leader and evolving into effective leaders themselves. Yet some participants voiced their lack of confidence in public speaking, and that their English proficiency was poor, which negatively affected their self-confidence. According to Doley (2010) English proficiency is the ability to read, write, speak and listen with understanding. Besides these concerns by the study 
participants, it appears that the finding of this study are in line with the International Institute of Medicine (IOM) consensus report (IOM, 2011) which found that nurses from the United States of America, for whom English is a second language, are regularly perceived to be incompetent by patients and other healthcare workers. They believe this is because their English proficiency is poor. Thus developing the ability to communicate more effectively could improve Generation Y nurses' self-confidence to lead.

\subsubsection{Bedside Leaders}

Generation Y nurses are keen to be developed in leadership and have the belief that they are able to be effective leaders. The findings are supported by Muller, Bezuidenhout and Jooste (2013) and Koloroutis (2004), who state that the process of leadership and the ability to lead can be found within everyone. This notion is also supported by Benne (1948) in his book titled: Leaders Are Made Not Born. This further supports the need to embrace the eagerness of Generation Y nurses to develop their leadership skills early in the career of a nurse, starting from the bedside. To improve their leadership skills and retain Generation Y nurses, Gomel (2015) cautions the profession not to ignore their leadership development needs, or they will resign from the organisation. The findings imply that bedside nursing in itself forms a solid basis for becoming an effective leader, regardless of whether the nursing activities are being experienced by a senior or junior nurse.

Due to the ever-changing intensity of modern healthcare, nurses are being stretched in every direction. One such way is that they are now expected to take on leadership roles earlier in their careers, including at the bedside, for example as preceptors to newly recruited nurses. These findings echo those of other authors (Honour, 2013; Klann, 2007; NHS, 2011; Porter-O'Grady, 2011), and although Alexander and Sysko (2012) found that Generation Y individuals want to be seen as effective leaders, Sherman, Dyess, and Prestia (2013) do not agree. The latter authors found that this generation consider themselves leaders yet they are not keen to assume leadership roles, because they are not convinced they will be adequately supported in the role. Furthermore they apparently fear failure (Sherman et al., 2015). Leadership support is thus important to bedside nurses, to equip them with the necessary tools to develop into effective leaders. This further reiterates that leadership development should begin much earlier in the career of a nurse.

\subsection{Theme 2: Teamwork}

\subsubsection{Knowing Self}

Because Generation Y nurses believe that leaders who are self-aware are more effective, they need to be educated on self-awareness, in order for them to develop as leaders. According to Fung (2011) there is a positive relationship between self-awareness and effective relationships with others. In addition there is a positive link between awareness of personal strengths and the ability to achieve goals (Linley et al., 2010), and this specifically applies to Generation Y (Chung \& Fitzsimons, 2013). Self-awareness facilitates understanding personal strengths and weaknesses, which is crucial to effective leadership of self and others. These findings support those of previous authors that self-awareness allows one to better lead oneself, which is a good foundation to lead others more effectively (Ashley \& Reiter-Palmon, 2012; Furtner, Baldegger, \& Rauthmann, 2013).

Generation Y nurses want to be treated fairly, which includes their desire to have equal opportunity to practice leadership at the bedside, and to not be overlooked as potential leaders. Leadership roles should not only be assigned to nurses who appear to be more confident. According to Park, Peterson, and Seligman (2004) fairness and justice are about treating everyone equally, disallowing personal feelings to influence decisions, and providing equal opportunities to everyone. De Braine and Verrier (2007) agree that fairness is one of the fundamental ethical values of character which is desired in leaders. Equality does not only apply to this generation, thus care should be applied to ensure there is no generational dominance. All team members' views should be regarded as important, thus according to Moore, Everly and Bauer (2016) equity and fairness are paramount. Similar findings are reported by Medyanik (2016) as well as Harmoinen et al. (2014) who found that young adult nurses in Finland perceive good management to involve equality. This notion is further supported by a study on the expectations of newly recruited Filipino nurses in London, which revealed that equal opportunity was one of the factors that affected their adjustment when it came to training and promotion opportunities (Daniel, Chamberlain, \& Gordon, 2000). Nursing leadership development should therefore encompass all generations, including the younger Generation Y.

\subsubsection{Relationships with Others}

According to Generation Y, team-building improves problem-solving and team spirit which in turn leads to a healthier practice environment (Manson, 2019). Generation Y apparently have high expectations of relationships at work (Medyanik, 2016), in fact when job-hunting, they place particular value on an organisation that provides congenial relationships between members on a team (Gomel, 2015; VanMeter et al., 2012). It has been said that 
this cohort thrives on the social connection with their peers (Cennamo \& Gardner, 2008), and according to Jamieson et al. (2015), it would be accurate to say that out of the four generations currently working together, Generation Y are the best team players. Generation Y individuals think in terms of collaboration at work when approaching tasks (Alexander \& Sysko, 2013; Tolbize, 2008; VanMeter et al., 2012) and decision-making (Woodward, Vongswasdi, \& More, 2015). This is not surprising since, when Generation Y individuals were growing up, their parents involved them in decision-making from a young age (Holt, Marques, \& Way, 2012).

Generation Y nurses believe good communication, especially listening skills are crucial to effective leadership and teamwork, which is consistent with the findings of McGrath (2014). No matter what level they are at, Generation Y nurses want their opinions considered in decision-making, which concurs with previous research (Kreitzer \& Koithan, 2015); in fact they expect it, regardless of how junior they may be in the workplace (Gomel, 2015).

\subsection{Theme 3: Professional Practice}

\subsubsection{Current Practice Environment}

Effective leadership lays the foundation for a well-organised work flow within a ward (Manson, 2019). These findings are congruent with those of D'Netto (2012) that Generation Y nurses value the quality of their working environment. Holland (2015) describes how strong leadership is the only hope of transforming the work environment, and that when nurses are satisfied at work, they contribute more. This implies that organisations should focus on fully engaging nurses if they hope to get the best performance out of them. In fact, Generation Y nurses judge an organisation by the working climate and team work, because according to them, this is what matters most (Lavoie-Tremblay et al., 2010). Additionally, Generation Y nurses value a supportive leader, which aligns with the findings of an Australian study (D'Netto, 2012) that talented Generation Y employees are an asset to organisations that offer greater flexibility and interesting work, in a pleasant environment with supportive leaders.

The fact that Generation Y nurses want to be listened to is a positive answer to the call by the WHO (2015) for nurses to make their voices heard in order to build effective healthcare leadership. The UN implores nurses for their crucial input to strengthen healthcare systems (ICN, 2016), and the ICN (2016) urges nursing leadership to be strengthened in order for the profession to be heard (ICN, 2016).

\subsubsection{Professional Growth}

There is a strong link between planning a career and development of employees, both on a personal and professional level. These findings are consistent with those of a previous study which concluded that professional development is necessary to augment leadership skills in all areas of nursing practice (Fardellone et al., 2014). The IOM (2011) urges healthcare to transform nursing education by encouraging nurses to embrace lifelong learning throughout their professional career. Generation Y nurses are apparently even more interested in learning when it has a direct impact on their career plans, as it feeds their desire to climb the ladder. It is thus important for the profession to develop the leadership of bedside nurses, because good leadership is also needed close to the point of care. Some healthcare organisations have responded to this need by creating clinical ladder programmes to offer bedside nurses the opportunity for professional growth (Fardellone et al., 2014). It would suffice to say that researchers are largely in agreement with the findings of the current study that Generation Y desire continued professional growth (Cheng, Filzah, \& Warangkana, 2015; Gomel, 2015; Harmoinen et al., 2014; Holt, Marques, \& Way, 2012).

At work Generation Y nurses prefer challenges to boredom, which is congruent with findings of other researchers (Alexander \& Sysko, 2013; Cheng, Filza, \& Warangkana, 2015; Chung \& Fitzsimons, 2013; D’Netto, 2012; Lavoie-Tremblay et al., 2010; Manson, 2019, Woodward, Vongswasdi, \& More, 2015). Generation Y should be assigned challenging tasks in order for them to showcase their technological expertise, even if it comes with the possibility of failure (Ferri-Reed, 2012). It is interesting to read that as far back as the 1950s and 1960s, Frederick Herzberg, the clinical psychologist known for his work on motivation theory, found that what satisfies employees is not the opposite of what dissatisfies them. Rather, employees are satisfied by intrinsic factors such as doing interesting, challenging work and being given increased responsibility, which feeds their innate need for growth and success (Herzberg, 1968). It is thus advisable to keep Generation Y nurses fully engaged in new and interesting projects.

\subsection{Resources}

\subsubsection{Previous Experience}

Generation Y nurses have gained leadership ability through many experiences. According to other authors, 
supervisors should meet the needs of the ambitious adrenaline-seeking Generation Y individuals by setting them challenges to keep them engaged (Cheng, Filzah, \& Warangkana, 2015; Holt, Marques, \& Way, 2012). Klann (2007) and Manson (2019) suggest stretching this generation with projects that take them out of their comfort zones to accelerate their professional growth.

\subsubsection{Future Expectations}

The findings are congruent with previous research that Generation Y enjoys having fun at work (D'Netto, 2012; Lester et al., 2012; Tew, Michel, \& Allen, 2014). Because they enjoy work that is unique, fun, challenging and interesting, they seek creative organisations (Gomel, 2015). In fact Holt, Marques and Way (2012) found this generation to like humour, silliness and even impudence at work. Even in the hospitality business, it was found that by promoting fun at work, Generation Y employees had a positive attitude, worked better in teams, were more satisfied at work and ultimately performed better on the job (Choi, Kwon, \& Kim, 2013). Porter-O'Grady (2011) proposes that by including an element of fun into leadership, it stimulates creativity across all levels of nursing.

According to the VIA institute on Character (2018), humour involves laughter, fun, teasing or joking. Fun-loving people cheer up the mood of others and they appear to be positive people. In addition to fun, Generation Y nurses are very comfortable with modern technology. The $21^{\text {st }}$ century is technology-driven (Manson, 2014) and because Generation Y nurses were technology-born; they do not know a time without instant messaging and the internet (Manson, 2019). Thus this cohort of individuals have been greatly influenced by the modern technology revolution (Thompson, 2015), which is changing leadership (Medyanik, 2016). According to Booth, Strudwick, and Fraser (2017) Generation $\mathrm{Y}$ individuals should be encouraged to establish innovative practices in order to transform healthcare.

Including leadership skills such as self-awareness, emotional management, critical thinking, problem-solving, decision-making and conflict management will meet the needs of Generation Y nurses. In agreement is Goleman (1998) who cautions that although self-awareness and social skills are critical to leadership development, technical skills cannot be ignored. General management expertise is necessary in leadership development (Conger \& Fulmer, 2003; Erdenk \& Altuntas, 2017; Medyanik, 2016). The IOM (2011) supports the findings of the study, when they recommend that future nursing education should include skills such as critical thinking, as a means of advancing nursing as a profession. Bearing in mind that Generation Y nurses desire a team-based approach at work, it would make sense to include team-based leadership skills as a focal point in leadership development programmes in the 21st century (Manson, 2019).

\subsection{Development of Leadership Framework}

The outcome of the study led to the creation of a leadership framework in phase three, which was developed from data collected on Generation Y nurses who work at the patients' bedside. The qualitative findings were afforded relative priority, in that the eight sub-themes which emerged from the coded data formed a skeleton. The quantitative data from two surveys was embedded in the sub-themes, which resulted in the formation of six domains in the leadership framework, seen in Figure 2. This framework will create appropriate opportunities for Generation Y nurses to grow as leaders, and prepare them to meet their full leadership potential.

Leadership is the pivotal element of healthcare success, because its aim is to meet the expectations of the people it serves. Leadership resides in the next generation of leaders who are shaped by a clear definition of leadership and regular processes for assessment and development of future leaders. Nurses are an integral part of any healthcare team, more especially as frontline nurses, where they should be actively and respectfully involved in all decisions, to fully embrace the term 'shared decision-making'. Nursing leadership concerns the ongoing development of nurses to reach the overarching aim of ensuring patient care that is safe and of a high quality. In addition to leaders needing to be confident and competent, they need to feel satisfied at work because they are on a clearly defined journey towards reaching their full potential, and because of this, they will provide excellent care.

The sustainability of the framework is established because it is not limited to once-off leadership development; it is intended to form part of a process that can be expounded upon as the personal and professional growth of each nurse unfolds. Sustaining anything takes will, energy and discipline. The leadership framework is intended for nurses to use interdependently with their supervisor's guidance, to gauge progress and to identify any obstacles that may have hindered progress. The supervisor should provide feedback on leadership performance regularly. The framework is not static, but rather it is flexible, to allow for career progression in any direction. Figure 2 provides an illustration of the leadership framework, comprising six core domains, in no particular sequence. 


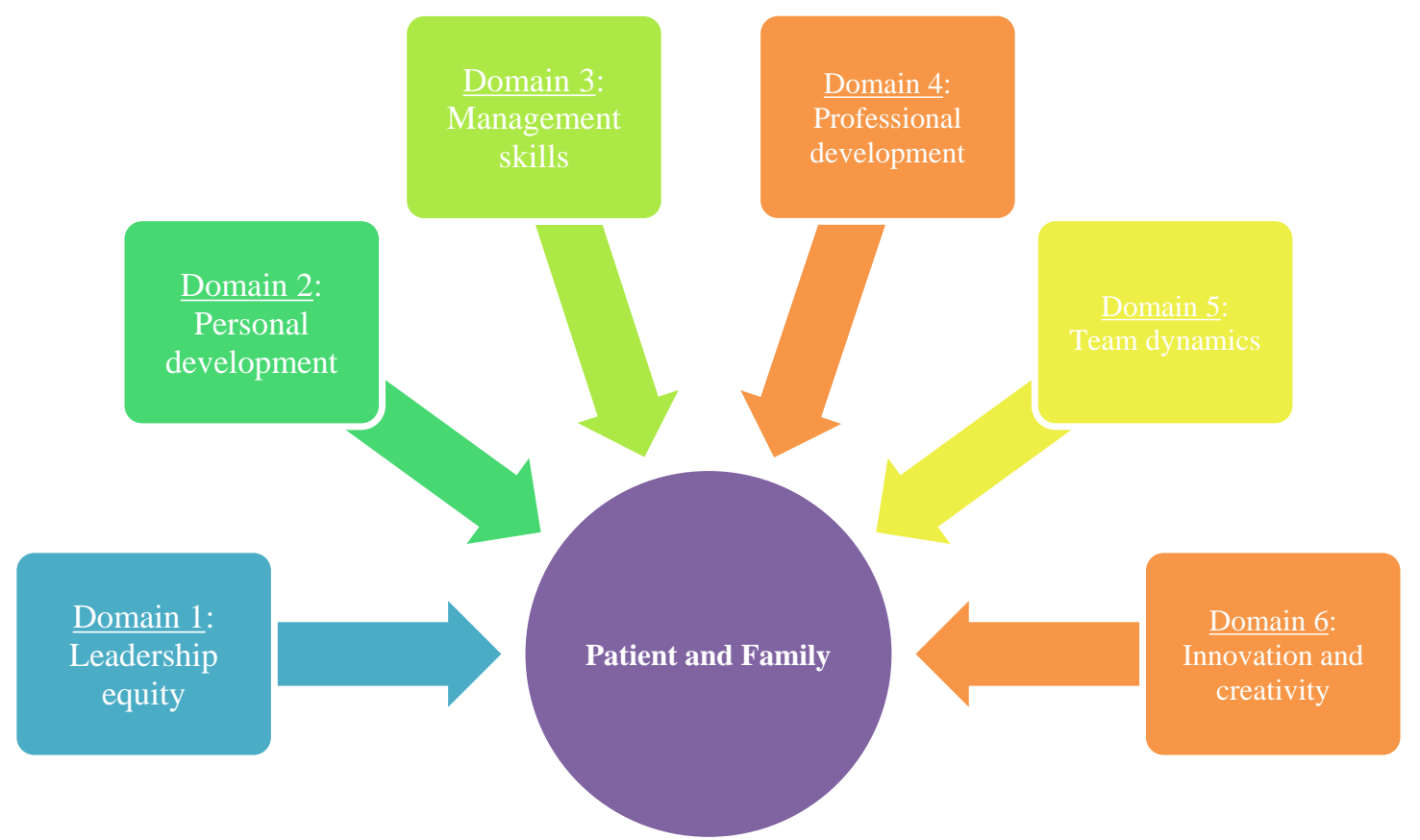

Figure 2. Proposed leadership framework for bedside nurses (Manson, 2019)

\section{Limitations of the Study}

The literature reports that generations across the globe have similar characteristics and needs. Although this study has found that the Generation Y sample display characteristics and needs that led to the development of the leadership framework revealed above, the potential utility of this framework at a global level requires further studies across other cultures, countries and linguistic groups.

\section{Recommendations}

\subsection{Education}

Generation Y nurses are in their first and second decade of nursing experience, which is an impressionable stage in any career. Career planning and professional development are high on the agenda of strategic Generation Y nurses. Strong mentors, formal career algorithms and dynamic leadership development education are required during this phase to get Generation Y nurses to the level needed to effectively lead the nursing profession. With the aim of improving leadership ability across all sectors of healthcare, leadership awareness should be a focus much earlier in the career of a nurse than it currently is, preferably at the inception of a nurse's career. Study findings could be considered for curriculum development, including the embedding of the proposed framework into undergraduate and postgraduate education programmes. The proposed framework could also be utilised as a foundation for advanced practice education in leadership for nurses.

\subsection{Management}

The researcher recommends that formal planning for the takeover of Generation Y nurses as leaders is imperative to ensure the success of the healthcare system in any country, because failing to plan leadership will be a case of planning to fail for the nursing profession. Generation Y nurses have a great deal to offer the healthcare industry; the industry should stop trying to change them, but rather be flexible to their distinctive needs, and this will result in a win-win for both parties.

\subsection{Further Research}

Healthcare research, and in particular leadership research, is well suited to the application of mixed methods and as such the researcher recommends that further mixed methods research be undertaken in health sciences. Since this study focused on nursing leadership development, it is recommended that further research could incorporate the unique characteristics of Generation $\mathrm{Y}$ nurses as presented in this and previous studies. These unique characteristics beg for the inclusion of humour, fun, creativity, innovation and technology in the nursing profession, because Generation Y value a healthy working environment with limitless potential. As leadership research incorporating qualitative data grows and strengthens, it is likely that the awareness of the potential of this method 
and other underrepresented methods will arouse researchers to consider leadership from other angles and hence suggest new research questions.

\section{Conclusion}

The younger generation has changed the traditional approach to leadership worldwide. This has had an impact on the healthcare sector, where leadership is said to be sorely lacking. Nursing in particular needs strong leaders, who can work as equals within the interdisciplinary team, which will improve patient outcomes. Effective leaders will also change the perception of nurses by the public as well as other interdisciplinary members. This study will ensure that nursing takes its rightful place in healthcare, alongside other healthcare professions, which is not the case right now. If every nurse is well prepared, it would create the impression that nurses are independent enough to stand alone as competent professionals within the multidisciplinary healthcare team. This situation gives good reason for the development of leaders amongst bedside nurses and this study will contribute to further advancement of the nursing profession globally.

The empirical evidence of this study suggests significant leadership needs of Generation Y nurses in a hospital setting, which validates the generational construct as a worthwhile and important concept in leadership development. Both the empirical evidence and the generational construct hold important implications for how today's younger generation in the nursing workforce are uniquely experiencing and influencing nursing. In turn, it may inform nursing management and leaders interested in leveraging the needs of this generation in order to maximise their potential in leading the future of the nursing profession.

\section{Competing Interests Statement}

The authors declare that there are no competing or potential conflicts of interests.

\section{References}

Alexander, C. S., \& Sysko, J. M. (2012). A study of the cognitive determinants of Generation Y's entitlement mentality. Academy of Educational Leadership Journal, 16(2), 63-68.

Alexander, C. S., \& Sysko, J. M. (2013). I'm gen Y, I love feeling entitled, and it shows. Academy of Educational Leadership Journal, 17(4), 127-131.

AlYami, M. S., \& Watson, R. (2014). An overview of nursing in Saudi Arabia. Journal of Health Specialties, 2(1), 10-12. https://doi.org/10.4103/1658-600X.126058

American Hospital Association (AHA). (2014). Managing an intergenerational workforce: Strategies for health care transformation. Retrieved from http://www.aha.org/about/cpi/managing-intergenerational-workforce.shtml

American Organization of Nurse Executives (AONE). (2015). The science, the art, the leader within: AONE nurse manager competencies. Chicago, IL: Author. Retrieved from http://www.aone.org

Ashley, G. C., \& Reiter-Palmon, R. (2012). Self-awareness and the evolution of leaders: The need for a better measure of self-awareness. Psychology Faculty Publications, 7, 2-17. Retrieved from https://digitalcommons.unomaha.edu/cgi/viewcontent.cgi?article=1006andcontext=psychfacpubBartlett

Bartlett, J. E., Kotrlik, J. W., \& Higgins, C. C. (2001). Organizational research: Determining appropriate sample size in survey research. Information Technology. Learning and Performance Journal, 19(1), 43-50.

Benne, K. D. (1948). Leaders are made, not born. Childhood Education, 24(5), 203-208. https://doi.org/10.1080/00094056.1948.10726014

Booth, R. G., Strudwick, G., \& Fraser, R. (2017). The transformative power of social media: Considerations for practice and emerging leaders. Healthcare Management Forum, 30, 138-141. https://doi.org/10.1177/0840470417693017

Byers, V. (2017). The challenges of leading change in health-care delivery from the front-line. Journal of Nursing Management, 25(6), 449-456. https://doi.org/10.1111/jonm.12342

Cennamo, L., \& Gardner, D. (2008). Generational differences in work values, outcomes and person-organisation values fit. Journal of Managerial Psychology, 23(8), 891-906. https://doi.org/10.1108/02683940810904385

Cheng, W. H., Filzah, M. I., \& Warangkana, T. (2015). A comparative study of leadership styles and leadership traits between gen X and Y: Malaysia as a case study. Australian Journal of Basic Applied Sciences, 9(28), $39-44$.

Choi, V. G., Kwon, J., \& Kim, W. (2013). Effects of attitudes vs experience of workplace fun on employee 
behaviors: Focused on Generation Y in the hospitality industry. International Journal of Contemporary Hospitality Management, 25(3), 410-427. https://doi.org/10.1108/09596111311311044

Chung, S. M., \& Fitzsimons, V. (2013). Knowing Generation Y: A new generation of nurses in practice. British Journal of Nursing, 22(20), 1173-1179. https://doi.org/10.12968/bjon.2013.22.20.1173

Conger, J. A., \& Fulmer, R. M. (2003). Developing your leadership pipeline. Harvard Business Review OnPoint, 5542, 1-10. Retrieved

from http://www.edanetworx.com/public_files/HBR-dev\%20your\%20leadership\%20pipeline.pdf

Creswell, J. W., Klassen, A. C., Plano Clark, V. L., \& Smith, K. C. (2011). Best practices for mixed methods research in the health sciences. Commissioned by the Office of Behavioral and Social Sciences Research (OBSSR). https://doi.org/10.1037/e566732013-001

Creswell, J. W., Plano Clark, V. L., Gutmann, M. J., \& Hanson, W. E. (2003). Advanced mixed methods research designs. In A. Tashakkori, \& C. Teddlie (Eds.), Handbook of mixed methods in social and behavioral research (pp. 159-196). Thousand Oaks: Sage.

Daniel, P., Chamberlain, A., \& Gordon, F. (2000). Expectations and experiences of newly recruited Filipino nurses. British Journal of Nursing, 10(4), 254-265. https://doi.org/10.12968/bjon.2001.10.4.5374

De Braine, R., \& Verrier, D. (2007). Leadership, character and its development: A qualitative exploration. South African Journal of Human Resource Management, 5(1), 1-10. https://doi.org/10.4102/sajhrm.v5i1.102

D'Netto, B. (2012). Generation Y: Human resource management implications. 1-9. Retrieved from https://pdfs.semanticscholar.org/f7d2/03a88ac80ead23725daf1029682854745b8d.pdf

Doley, J. (2010). English as a second language dietetics students: Lessons from nursing to facilitate learning experiences in dietetic internships. Journal of the American Dietetic Association, 110(12), 1806-1809. https://doi.org/10.1016/j.jada.2010.10.017

Dyess, M., Sherman, R. O., Pratt, B. A., \& Chiang-Hanisko, L. (2016). Growing nurse leaders: Their perspectives on nursing leadership and today's practice environment. OJIN: The Online Journal of Issues in Nursing, $21(1)$.

Erdenk, N., \& Altuntaş, S. (2017). Do personality traits of nurses have an effect on conflict management strategies? Journal of Nursing Management, 25(5), 366-374. https://doi.org/10.1111/jonm.12474

Fabrey, L. J., \& Traynor, C. (2014). National practice analysis study for the nurse manager and leader. Certification course for the American Organization of Nurse Executives: 1. Retrieved from http://www.goAMP.com

Fardellone, C., Musil, C. M., Smith, E., \& Click, E. R. (2014). Leadership behaviors of frontline staff nurses. The Journal of Continuing Education in Nursing, 45(11), 506-513. https://doi.org/10.3928/00220124-20141023-05

Ferri-Reed, J. (2012). Three ways leaders can help Millennials succeed. The Journal for Quality and Participation, 35(1), 18-19.

Fetters, D. A., Curry, L. A., \& Creswell, J. W. (2013). Achieving integration in mixed methods designs - principles and practices. Health Services Research, 48(6), 2134-2156. https://doi.org/10.1111/1475-6773.12117

Fung, C. (2011). Exploring individual self-awareness as it relates to self-acceptance and the quality of interpersonal relationships. M.Sc. (Organization Development). The George L. Graziadio School of Business and Management.

Furtner, M. R., Baldegger, U., \& Rauthmann, J. F. (2013). Leading yourself and leading others: Linking self-leadership to transformational, transactional, and laissez-faire leadership. European Journal of Work and Organizational Psychology, 22(4), 436-449. https://doi.org/10.1080/1359432X.2012.665605

Goleman, D. (1998). What makes a leader? Harvard Business Review, 93-102. Retrieved from https://files.transtutors.com/cdn/uploadassignments/2365761_1_contentserver.pdf

Gomel, D. (2015). Retaining behavioral healthcare employees of the Millennial generation. Doctorate (Social and Behavioural Sciences), Walden University.

Grossman, S. C., \& Valiga, T. M. (2017). The new leadership challenge: Creating the future of nursing (5th ed.). Philadelphia: F.A. Davis. 
Harmoinen, M., Niiranen, K., Niiranen, V., Åstedt-KurKi, P., \& Suominen, T. (2014). Stories of management in the future according to young adults and young nurses. Contemporary Nurse, 47(1-2), 69-78. https://doi.org/10.5172/conu.2014.4331

Hendricks, J. M., \& Cope, V. C. (2012). Generational diversity: What nurse managers need to know. Journal of Advanced Nursing, 69(3), 717-725. https://doi.org/10.1111/j.1365-2648.2012.06079.x

Herzberg, F. (1968). One more time: How do you motivate employers? Harvard Business Review, January, 3-11. $\begin{array}{lllll}\text { Retrieved } & 1 & \text { June } & 2018 & \text { from }\end{array}$ https://pdfs.semanticscholar.org/a3a4/05aff963b2d6d252e8ae136cde06508c0010.pdf

Hewitt, M. L. M., \& Upkere, W. I. (2012). Leadership challenges associated with the management of Generation Y employees: A proposed theoretical model. African Journal of Business Management, 6(19), 5999-6004. https://doi.org/10.5897/AJBM12.533

Holland, C. (2015). Investing in our nursing workforce. Nursing Management, 46(9), 8-10. https://doi.org/10.1097/01.NUMA.0000470775.02484.c0

Holt, S., Marques, J., \& Way, D. (2012). Bracing for the Millennial workforce: Looking for ways to inspire Generation Y. Journal of Leadership, Accountability and Ethics, 9(6), 81-93.

Honour, M. (2013). Elevating nursing leadership at the bedside. Newborn and Infant Reviews, 13(3), 127-130. https://doi.org/10.1053/j.nainr.2013.06.009

Institute of Medicine (IOM). (2011). The future of nursing: Leading change, advancing health. Washington, DC: National Academies Press. Retrieved from https://www.nap.edu/read/12956/chapter/1\#ix

International Council of Nurses (ICN). (2016). Applications open for 2016 ICN Global Nursing Leadership Institute. 17-23 September 2016. Press information. Geneva, Switzerland.

Jamieson, I., Kirk, R., Wright, S., \& Andrew, C. (2015). Generation Y New Zealand registered nurses' views about nursing work: A survey of motivation and maintenance factors. Nursing Open, 49-61. https://doi.org/10.1002/nop2.16

Klann, G. (2007). Building character: Strengthening the heart of good leadership. San Francisco: Jossey-Bass and the Center for Creative Leadership.

Koloroutis, M. (2004). Relationship-based care: A model for transforming practice. Minneapolis: Creative Health Care Management.

Kotter, J. P. (2013). Management is (still) not leadership. Harvard Business Review, n.p.

Kreitzer, M. J., \& Koithan, M. (2015). Integrative nursing. Oxford: Oxford University Press. https://doi.org/10.1093/med/9780199860739.001.0001

Lavoie-Tremblay, M., Leclerc, E., Marchionni, C., \& Drevniok, U. (2010). The needs and expectations of Generation $\mathrm{Y}$ nurses in the workplace. Journal for Nurses in Staff Development, 26(1), 2-8. https://doi.org/10.1097/NND.0b013e3181a68951

Lester, S. C., Standifer, R. L., Schultz, N. J., \& Windsor, J. M. (2012). Actual versus perceived generational differences at work: An empirical examination. Journal of Leadership and Organizational Studies, 19(3), 341-354. https://doi.org/10.1177/1548051812442747

Lincoln, Y. S., \& Guba, E. G. (1985). Naturalistic inquiry. Newbury Park, CA: Sage. https://doi.org/10.1016/0147-1767(85)90062-8

Linley, P. A., Nielsen, K. M., Gillett, R., \& Biswas-Diener, R. (2010). Using signature strengths in pursuit of goals: Effects on goal progress, need satisfaction, and well-being, and implications for coaching psychologists. International Coaching Psychology Review, 5(1), 6-15.

Littman-Ovadia, H., Lavy, S., \& Boiman-Meshita, M. (2016). When theory and research collide: Examining correlates of signature strengths use at work. Journal of Happiness Studies, 2017(18), 527-548. https://doi.org/10.1007/s10902-016-9739-8

Manson, T. A. (2014). A relationship between matriculation English results and academic performance in nursing students at the KwaZulu-Natal College of Nursing. M.Tech (Health Sciences), Durban University of Technology, South Africa.

Manson, T. A. (2019). The leadership potential of Generation Y practitioner nurses: Basis for a leadership 
framework. PhD (Health Sciences), Durban University of Technology, South Africa.

McGrath, R. E. (2014). Scale- and item-level factor analyses of the VIA Inventory of Strengths. Assessment, 21(1), 4-14. https://doi.org/10.1177/1073191112450612

Medyanik, K. K. (2016). A holistic, qualitative case study regarding the leadership traits and styles of the millennial generation. Doctorate (Business Administration), Prescott Valley, Arizona.

Mitchell, P. H. (2015). Nursing and universal health coverage. International Nursing Review, 62, 283-284. https://doi.org/10.1111/inr.12212

Moore, J. M., Everly, M., \& Bauer, R. (2016). Multigenerational challenges: Team-building for positive clinical workforce outcomes. The Online Journal of Issues in Nursing, 21(2). Retrieved 12 September 2018 from http://ojin.nursingworld.org/MainMenuCategories/ANAMarketplace/ANAPeriodicals/OJIN/TableofContent s/Vol-21-2016/No2-May-2016/Multigenerational-Challenges.html

Muller, M., Bezuidenhout, M., \& Jooste, K. (2013). Healthcare service management (2nd ed.). Cape Town: Juta.

National Health System (NHS) Institute for Innovation and Improvement. (2011). Leadership framework: Self-assessment tool. Retrieved from http://www.nhsleadership.org.uk/framework.asp

Nelsey, L., \& Brownie, S. (2012). Effective leadership, teamwork and mentoring: Essential elements in promoting generational cohesion in the nursing workforce and retaining nurses. The Australian Journal of Nursing Practice, Scholarship and Research, 9(4), 197-202. https://doi.org/10.1016/j.colegn.2012.03.002

Neu, L. (2017). Leadership Development for the Formal Nurse Leader. Doctorate (Health Science), Walden University.

Park, N., Peterson, C., \& Seligman, M. P. (2004). Strengths of character and well-being. Journal of Social and Clinical Psychology, 23(5), 603-619. https://doi.org/10.1521/jscp.23.5.603.50748

Polit, D. F., \& Beck, C. T. (2012). Nursing research: Generating and assessing evidence for nursing practice (9th ed.). Philadelphia. Lippincott, Williams and Wilkins.

Porter-O'Grady, T. (2011). Leadership at all levels. Nursing Management, 42(5), 32-37. https://doi.org/10.1097/01.NUMA.0000396347.49552.86

Sherman, R. O., Dyess, S., \& Prestia, E. A. (2013). Succession planning for the future through an academic-practice partnership. Nursing Administration Quarterly, 37(1), 18-27. https://doi.org/10.1097/NAQ.0b013e31827514ba

Sherman, R. O., \& Pross, E. (2010). Growing future nurse leaders to build and sustain healthy work environments at the unit level. OJIN: The Online Journal of Issues in Nursing, 15(1).

Sherman, R. O., Saifman, H., Schwartz, R. C., \& Schwartz, C. L. (2015). Factors that lead Generation Y nurses to consider or reject nurse leader roles. Nursing Plus Open, 1, 5-10. https://doi.org/10.1016/j.npls.2015.05.001

Stanley, D. (2010). Multigenerational workforce issues and their implications for leadership in nursing. Journal of Nursing Management, 18, 846-852. https://doi.org/10.1111/j.1365-2834.2010.01158.x

Tesch, R. (1990). Qualitative research: Analysis types and software tools. Bristol: Falmer Press.

Tew, M. J., Michel, J. W., \& Allen, D. G. (2014). Fun and friends: The impact of workplace fun and constituent attachment on turnover in a hospitality context. Human Resources, 67(8), 923-946. https://doi.org/10.1177/0018726713508143

Thompson, E. (2015). The modern puer: Disillusionment and Generation Y. M.A. (Counselling Psychology), Pacifica Graduate Institute.

Tolbize, A. (2008). Generational differences in the workplace. Minneapolis, MN: University of Minnesota Research and Training Center on Community Living. Retrieved from https://rtc3.umn.edu/docs/2_18_Gen_diff_workplace.pdf

Tulgan, B. (2009). Not everyone gets a trophy: How to manage Generation Y. San Francisco: Jossey-Bass.

Values in Action Institute (VIA) on Character. (2017). Retrieved 18 March 2018 from https://www.viacharacter.org/www/Portals/0/VIA\%20Classification\%202017.pdf

Values in Action Institute (VIA) on Character. (2018). Retrieved 13 June 2019 from https://www.viacharacter.org/www/Reports-Courses-Resources/Resources/Character-Strength-Fact-Sheets 
VanMeter, R. A., Grisaffe, D. B., Chonko, L. B., \& Roberts, J. A. (2012). Generation Y's ethical ideology and its potential workplace implications. Journal of Business Ethics, 117(1), 93-109. https://doi.org/10.1007/s10551-012-1505-1

West, M., Ackert, R., Steward, K., \& Pasmore, B. (2014). Developing collective leadership for health care. The Kings $\quad$ Fund. $\quad$ Retrieved $1 \quad$ June 2018 from http://www.ctrtraining.co.uk/documents/DevelopingCollectiveLeadership-KingsFundMay2014.pdf

Woodward, I. C., Vongswasdi, P., \& More, E. A. (2015). Generational diversity at work: A systematic review of the research. National Society for Education and Art Design (NSEAD) Working Paper Series, 2015/48/OB. https://doi.org/10.2139/ssrn.2630650

World Health Organization (WHO). (2013). Research for universal health coverage. World Health Report. $\begin{array}{llll}\text { Retrieved } & 2 & \text { November } & 2016\end{array}$ http://apps.who.int/iris/bitstream/10665/85761/2/9789240690837_eng.pdf

World Health Organization (WHO). (2015). Health workforce and services. Draft global strategy on human resources for health: Workforce 2030. Report by the secretariat, EB 138/36 Geneva: World Health Organization.

\section{Copyrights}

Copyright for this article is retained by the author(s), with first publication rights granted to the journal.

This is an open-access article distributed under the terms and conditions of the Creative Commons Attribution license (http://creativecommons.org/licenses/by/4.0/). 